\title{
Estimates of Combining Ability and Cluster Analysis for Some Rice Vareities
}

\section{(Oryza sativa $\mathbf{L}$.)}

\author{
Abd El-Hadi A.H ${ }^{1}$; Z.M. El-Diasty ${ }^{1}$; S.A.A.Hammoud ${ }^{2}$ and A.M.A.El-Badri ${ }^{2}$
}

\begin{abstract}
The present study was carried out during 2009 and 2010 growing seasons at Rice Research and Training Center (RRTC) Farm, at Sakha, Kafr El-Sheikh Egypt. Eight Egyptian genotypes i.e., five commercial varieties (Giza177, Sakha101, Sakha104, Sakha105 and Sakha106), one promising lines $(\mathrm{Gz}$ 7576-10-3-2-1) and two international deferential varieties (BL1 and Shien2). The eight genotypes were sown in the summer growing season of (2009) in three sowing dates. A half diallel design was conducted among the eight parents to produce twenty eight crosses. Eight genotypes and their 28 hybrids were studied for nine traits e.i, plant height, No. of days to heading, No. of panicles plant $^{-1}$, grain yield plant ${ }^{-1}, 1000$-grain weight, spikelets fertility $\%$, hulling $\%$, milling $\%$ and head rice $\%$. The mean square of genotypes, parents, crosses and parents vs. crosses revealed highly significant variations for all traits under investigation. Both general combining ability and specific combining ability variances were found to be highly significant for all studies traits. The GCA/SCA variance were found to be greater than unity for No. of days to heading and 1000-grain weight, indicating that, additive and additive $x$ additive types of gene action were of greater importance in the inheritance of these traits but the another studied traits the non-additive type were great important in plant height, No. of panicle plant ${ }^{-1}$, grain yield plant $^{-1}$, spikelets fertility $\%$, hulling $\%$, milling\% and head rice\%. The five rice varieties Sakha105, Sakha106, GZ7576-10-3-2-1, BL1 and Shien2 showed highly significant negative GCA effects for No. of days to heading, while Giza177, Sakha101 and Shien2 exhibited significant negative GCA effects (desirable) for plant height. Sakha 101 exhibited highly significant positive GCA effects for No. of panicles plant ${ }^{-1}$. The two rice varieties Sakha101 and Sakha104 which proved to be excellent combiners for grain yield plant $^{-1}$ would be of practical interest in a breeding program towards developing high yielding genotypes. Fourteen out of the twenty eight hybrid combinations showed highly significant negative SCA effects for No. of days to heading. Twenty out of the twenty eight $F_{1}$ hybrids exhibited highly significant desirable SCA effects for grain yield plant $^{-1}$. These superior twenty crosses were previously found to express useful heterosis. Clustering varieties based on similarity of quantitative characters produced tow large groups. The first group, included Sakha 101 and Sakha 104 these two similar varieties in heading average was 107.5 days. The second group included all short days to heading, the average of those varieties was 91.6 days.
\end{abstract}

\footnotetext{
${ }^{1}$ Genetics Department, Fac. of Agric. Mansoura University, Egypt.

${ }^{2}$ Rice Research and Training Center, Sakha, Kafr El-Sheikh, Egypt. Received November 17, 2012, Accepted December 27, 2012.
}

\section{INTRODUCTION}

Rice is one of the most important staple foods for about one-half of the human race. About one-third of man kind (1.3 billion people) depends on rice more than half of its food (Annual report of International Rice Research Institute, IRRI, 1996). Rice is considered the most popular and important field crop in Egypt for several reason: as a staple food after wheat; as a second exporting crop after cotton; as a land reclamation crop for improving the productivity of the saline soils widely spread in North Delta and coastal area; and finally it is asocial crop in which every person in the farmers family could find work in rice fields and gain money during the growing season. Rice crop plays a significant role in Egypt's strategy for sustaining the food self-sufficiency and for increasing the export. In 2005 season, the total rice production in Egypt reached 6.6 million tons with a national average of 10.00 tons/ha. This average ranked the first among the rice producing countries in the world (RRTC 2006). Further increase in rice production through increased yield per unit area is needed. Continuously, rice breeders and producers looking for new technology and new lines, which increase rice production with acceptable grain quality. Rice production should increase by about $60 \%$ by the year 2025 to feed the additional rice consumers (Duwayri et al., 1999). Increasing rice production has been a problem due to limited land available and water shortage.

\section{MATERIALS AND METHODS}

This study was conducted at Rice Research and Training Center (RRTC), Sakha, Kafr El-Sheikh, Egypt during 2009 and 2010 growing seasons. The study involving eight rice Egyptian genotypes i.e., five commercial varieties (Giza177, Sakha101, Sakha104, Sakha105 and Sakha106), one promising lines (GZ757610-3-2-1) and two international deferential varieties (BL1 and Shien2). The eight genotypes were sown in the summer growing season of (2009) in three sowing dates. A half diallel design was conducted among the eight parents to produce twenty eight crosses. The hybridization technique of Jodon (1938) and modified by Butany (1961), was utilized. The parental varieties and the resulted crosses evaluated in a Randomized Complete Block Design (RCBD) experiment with three 
replications in 2010 growing season. Each replication had twenty five individual plants from each genotype. Data have been collected on plant height $(\mathrm{cm})$, No. of days to heading (days), No. of panicles plant ${ }^{-1}$, grain yield plant $^{-1}(\mathrm{~g})$, 1000-grain weight $(\mathrm{g})$, spikelets fertility $\%$, hulling $\%$, milling $\%$ and head rice $\%$ according to the standard evaluation system of IRRI (1996). In 2010 growing season the eight genotypes were crossed in a half diallel design, combining ability analysis were carried out according to model 1 , method 2 of Griffing (1956). The cluster analysis was conducted using the Numerical Taxonomy and Multivariate Analysis System, Version 2.1 (NTSYSpc; Rohlf, 2000).

\section{RESULTS AND DISCUSSION}

\section{1- Mean performance:}

The mean performance of parental varieties and their $28 \mathrm{~F}_{1}$ hybrids for all studied traits are presented in Table(1). Regarding plant height the shortest plant height is desirable. The two parents Shien2 and Sakha101 gave the lowest mean values of 85.4 and 92.3 $\mathrm{cm}$ respectively. The $\mathrm{F}_{1}$ generation had the highest values compared with parents indicated that the F1 generation, posses the over dominance for this trait. For days to heading the most desirable mean values towards the earliness were obtained from the parents GZ757610-3-2-1, Sakha 106 and shien2 which gave the lowest mean values of 92.0, 93.0 and 93.3 days, respectively. On the other hand, results recorded that the crosses BL1 $\times$ Shien 2 and Sakha101 $\times$ Sakha105 gave the same mean values for No. of days to heading (earliness) with the mean values of 92.0 days. While the crosses Sakha $105 \times$ Sakha 106, Sakha 106×Shien 2, GZ7576-10-3-2$1 \times$ BL1 and GZ7576-10-3-2-1×Shien 2 recorded 93.0 days to heading. These results revealed that the old variety sakha101 was the later parent for No. of days to heading. As for No. of panicles plant ${ }^{-1}$, the highest mean values were obtained from the parents Sakha101 and Sakha105 (23.0 and 22.0 panicles respectively), but Giza177 gave the lowest mean values 19.6 panicles plant $^{-1}$. These results were also obtained by Rahimi et al., (2010), Kelah (2012) and El-Malky and Hammoud (2012).

Regarding to grain yield plant ${ }^{-1}$ the parents Sakha101 and Sakha105 recorded the highest mean values of 52.0 and 46.0 gram plant $^{-1}$ respectively. While the highest mean values were found in the crosses Giza177 $\times$ Sakha106, Sakha101 × Sakha104, Sakha101 × GZ757610-3-2-1, Sakha104 $\times$ Sakha106, Sakha105 $\times$ BL1 and Sakha106 $\times$ BL1 with mean values ranged from 81.85 to 87.20 gram plant $^{-1}$. But the crosses Sakha104×GZ757610-3-2-1 and GZ7576-10-3-2-1 $\times$ BL1 gave the lowest mean values for grain yield plant ${ }^{-1}$ which were 57.37 and 56.33 gram plant $^{-1}$, respectively. Concerning to $1000-$ grain weight, the mean values of the parental varieties showed that Sakha101 and Sakha106 exhibited highest 1000-grain weight with the mean values 29.0 and 28.5 (g), respectively, but the parent GZ7576-10-3-2-1 gave the lowest mean value $26.2(\mathrm{~g})$. The hybrid combination GZ7576-10-3-2-1 $\times$ BL1 gave the highest 1000 grain weight $29.8 \mathrm{~g}$. While, Sakha101 $\times$ Shien 2 gave the lowest mean value $26.2(\mathrm{~g})$, for the same trait.

Concerning to spikelets fertility\% the parental varieties Sakha105 and Shien2 recorded the lowest mean values of (89 and 82 respectively), but Giza177 and Sakha104 gaves the highest mean values of (95 and 96, respectively). On the other hand, the hybrids combinations Giza177 × Sakha104, Sakha106 × Shien2 and GZ7576-10-3-2-1 $\times$ Shien2 recorded the highest mean values (93.45, 93.93 and $94.50 \%$, respectively), but the crosses Sakha104 $\times$ Sakha105 and Sakha104 $\times$ BL1 gave the lowest mean values of 61.37 and 66.16, respectively.

For hulling\%, the parental variety Giza177 exhibited the highest mean value of $82.47 \%$, while Sakha105 exhibited the lowest mean value of $79.58 \%$. On the other hand the crosses Sakha105 $\times$ BL1 and Sakha104 $\times$ GZ7576-10-3-2-1, exhibited highest mean values of 81.90 and $81.74 \%$, respectively. While, Giza177 $\times$ Sakha106 and Sakha101 $\times$ Shien2 had the lowest mean values of 79.94 and $79.68 \%$, respectively. Regarding milling $\%$, the parental variety BL1 recorded the highest mean value of $72.36 \%$, while Sakha106 recorded the lowest mean value $70.46 \%$. On the other hand the hybrid combinations Sakha105 $\times$ BL1 and Sakha105 $\times$ Shien 2 gave the highest mean values of 72.38 and $72.21 \%$, respectively. While the four crosses Sakha101 x Shien2, Giza177 x BL1, Sakha x BL1 and BL1 x Shien2 exhibited the lowest mean values for milling $\%$ with mean values of $69.71,70.24,70.24$ and $70.67 \%$, respectively.

For head rice \%, the highest mean values were obtained from the parent Giza177 (65.37\%) but, Sakha 106 gave the lowest mean value $(61.70 \%)$. On the other hand the five crosses Giza177 $\times$ Shien2, Sakha101 $\times$ Sakha 105, Sakha104 $\times$ Shien2, GZ7576-10-3-2-1 $\times$ BL1 and GZ7576-10-3-2-1 $\times$ Shien2 gave the highest mean values ranged from 65.06 to $65.67 \%$, but the crosses Giza177 x GZ7576-10-3-2-1, Giza177 x Sakha105, Skha101 x Sakha106, Sakha104 x GZ757610-3-2-1 and Sakha101 x GZ7576-10-3-2-1 gave the lowest mean values $60.95,61.09,61.17,61.47$ and 61.61 respectively. These resulted were also obtained by Rahimi et al., (2010) and El-Malkyand Hammoud (2012). 
Table 1. Mean performance of parental varieties and their $F_{1}$ crosses for all studied characters

\begin{tabular}{|c|c|c|c|c|c|c|c|c|c|c|}
\hline No & Genotypes & $\begin{array}{l}\text { Plant } \\
\text { height } \\
(\mathrm{cm})\end{array}$ & $\begin{array}{l}\text { Days to } \\
\text { heading } \\
\text { (days) }\end{array}$ & $\begin{array}{c}\text { No-of } \\
\text { panicles } \\
\text { plant }^{-1}\end{array}$ & $\begin{array}{c}\text { Grain } \\
\text { yield } \\
\text { plant }^{-1} \\
(\mathrm{~g})\end{array}$ & $\begin{array}{c}1000- \\
\text { grain } \\
\text { weight } \\
\text { (g) }\end{array}$ & $\begin{array}{c}\text { Spikelet } \\
\text { fertility } \\
\%\end{array}$ & $\begin{array}{c}\text { Hulling } \\
(\%)\end{array}$ & $\begin{array}{c}\text { Milling } \\
(\%)\end{array}$ & $\begin{array}{c}\text { Head } \\
\text { rice }(\%)\end{array}$ \\
\hline 1 & Giza 177 & 98.0 & 95.0 & 19.6 & 45.00 & 28.0 & 95.00 & 82.47 & 71.88 & 65.37 \\
\hline 2 & Sakha 101 & 92.3 & 110.0 & 23.0 & 52.00 & 29.0 & 90.50 & 81.32 & 71.51 & 64.31 \\
\hline 3 & Sakha 104 & 105.0 & 105.0 & 21.0 & 44.00 & 27.1 & 96.00 & 81.47 & 72.01 & 64.42 \\
\hline 4 & Sakha 105 & 95.0 & 95.0 & 22.0 & 46.00 & 28.0 & 89.00 & 79.58 & 70.89 & 61.78 \\
\hline 5 & Sakha 106 & 105.9 & 93.0 & 20.0 & 45.00 & 28.5 & 90.00 & 80.01 & 70.46 & 61.70 \\
\hline 6 & GZ 7576-10-3-2-1 & 102.2 & 92.0 & 21.0 & 37.00 & 26.2 & 92.00 & 81.39 & 70.96 & 64.63 \\
\hline 7 & BL 1 & 98.0 & 97.0 & 21.0 & 35.00 & 27.7 & 94.03 & 81.38 & 72.36 & 62.35 \\
\hline 8 & Shien 2 & 85.4 & 93.3 & 20.9 & 33.00 & 27.6 & 82.00 & 80.97 & 71.90 & 64.87 \\
\hline 9 & Giza $177 \times$ Sakha101 & 104.7 & 111.0 & 26.7 & 76.15 & 28.7 & 85.62 & 80.67 & 71.31 & 64.30 \\
\hline 10 & Giza $177 \times$ Sakha 104 & 111.1 & 96.0 & 25.6 & 75.32 & 27.7 & 93.45 & 80.67 & 71.52 & 62.16 \\
\hline 11 & Giza 177× Sakha 105 & 113.9 & 110.0 & 26.0 & 63.17 & 29.2 & 80.25 & 80.62 & 70.87 & 61.09 \\
\hline 12 & Giza 177× Sakha 106 & 112.3 & 98.0 & 27.0 & 83.87 & 28.7 & 82.25 & 79.94 & 70.78 & 64.55 \\
\hline 13 & Giza $177 \times$ GZ7576-10-3-2-1 & 108.1 & 97.3 & 26.8 & 69.30 & 28.8 & 78.43 & 80.19 & 71.08 & 60.95 \\
\hline 14 & Giza $177 \times$ BL 1 & 109.8 & 98.0 & 26.6 & 65.64 & 28.5 & 74.75 & 80.99 & 70.24 & 64.20 \\
\hline 15 & Giza $177 \times$ Shien 2 & 112.3 & 100.0 & 24.3 & 58.97 & 28.9 & 73.40 & 80.41 & 71.10 & 65.10 \\
\hline 16 & Sakha $101 \times$ Sakha 104 & 117.8 & 99.0 & 25.9 & 81.85 & 27.3 & 85.09 & 80.42 & 71.27 & 62.00 \\
\hline 17 & Sakha $101 \times$ Sakha 105 & 119.3 & 92.0 & 27.5 & 74.20 & 27.7 & 78.49 & 80.91 & 70.73 & 65.67 \\
\hline 18 & Sakha $101 \times$ Sakha 106 & 110.7 & 116.0 & 26.9 & 64.02 & 28.2 & 68.74 & 80.96 & 71.31 & 61.17 \\
\hline 19 & Sakha $101 \times$ GZ7576-10-3-2-1 & 109.6 & 113.0 & 25.1 & 87.20 & 26.6 & 70.55 & 81.16 & 71.25 & 61.61 \\
\hline 20 & Sakha $101 \times$ BL 1 & 110.1 & 111.0 & 29.4 & 74.04 & 28.0 & 69.80 & 81.04 & 70.24 & 63.59 \\
\hline 21 & Sakha $101 \times$ Shien 2 & 112.4 & 116.0 & 27.1 & 77.26 & 26.2 & 66.36 & 79.68 & 69.71 & 64.48 \\
\hline 22 & Sakha $104 \times$ Sakha 105 & 124.9 & 117.0 & 26.1 & 73.27 & 27.0 & 61.37 & 81.40 & 71.38 & 62.82 \\
\hline 23 & Sakha $104 \times$ Sakha 106 & 117.1 & 99.0 & 25.6 & 84.42 & 27.6 & 86.45 & 81.49 & 70.79 & 62.83 \\
\hline 24 & Sakha $104 \times$ GZ7576-10-3-2-1 & 122.0 & 112.0 & 23.6 & 57.37 & 28.6 & 85.83 & 81.74 & 71.30 & 61.47 \\
\hline 25 & Sakha $104 \times$ BL 1 & 115.9 & 104.0 & 23.0 & 73.47 & 27.1 & 66.16 & 80.41 & 70.91 & 64.64 \\
\hline 26 & Sakha $104 \times$ Shien 2 & 116.5 & 103.0 & 22.7 & 72.91 & 26.9 & 81.34 & 81.19 & 70.70 & 65.48 \\
\hline 27 & Sakha 105× Sakha 106 & 111.3 & 93.0 & 25.7 & 57.76 & 28.7 & 77.48 & 80.52 & 71.43 & 64.89 \\
\hline 28 & Sakha $105 \times$ GZ7576-10-3-2-1 & 112.1 & 94.0 & 26.1 & 68.00 & 28.4 & 84.14 & 80.38 & 71.39 & 64.86 \\
\hline 29 & Sakha $105 \times$ BL 1 & 117.0 & 97.0 & 27.2 & 83.64 & 28.3 & 85.43 & 81.90 & 72.38 & 63.38 \\
\hline 30 & Sakha $105 \times$ Shien 2 & 116.3 & 94.0 & 23.5 & 63.83 & 28.8 & 88.24 & 81.14 & 72.21 & 63.09 \\
\hline 31 & Sakha $106 \times$ GZ7576-10-3-2-1 & 115.4 & 91.7 & 28.0 & 58.17 & 28.8 & 77.77 & 81.29 & 71.40 & 62.57 \\
\hline 32 & Sakha $106 \times$ BL 1 & 124.4 & 100.3 & 27.0 & 83.24 & 28.2 & 82.40 & 81.07 & 71.21 & 63.90 \\
\hline 33 & Sakha $106 \times$ Shien 2 & 117.5 & 93.0 & 25.4 & 69.30 & 28.5 & 93.93 & 81.39 & 71.71 & 64.03 \\
\hline 34 & GZ7576-10-3-2-1× BL 1 & 116.5 & 93.0 & 26.5 & 56.33 & 29.8 & 92.69 & 81.79 & 71.44 & 65.06 \\
\hline 35 & GZ7576-10-3-2-1× Shien 2 & 115.7 & 93.0 & 27.3 & 79.39 & 27.8 & 94.50 & 81.53 & 70.86 & 65.12 \\
\hline 36 & BL $1 \times$ Shien 2 & 110.8 & $` 92.0$ & 23.8 & 57.34 & 27.4 & 91.37 & 79.98 & 70.67 & 63.71 \\
\hline
\end{tabular}




\section{2- Analysis of variation:-}

The ordinary analysis of variance for all genotypes and combining ability for the studied characters attributes are presented in Table (2). Highly significant mean squares were observed for genotype, parents, crosses and parent vs. crosses for all studied traits i.e. plant height, days to heading, No. of panicles plant ${ }^{-1}$, grain yield plant $^{-1}, 1000$-grain weight, spikelets fertility $\%$, hulling $\%$, milling $\%$ and head rice $\%$. This finding indicated the presence of large variation among the studied genotypes and portion of these genotypic variances to its component are varied.

Parent vs. Crosses mean square as an indication to average heterosis overall crosses, were found to be highly significant for all studied characters under investigation. These resulted were also obtained by Rahimi et al., (2010) and El-Malky and Hammoud (2012).

Estimates of both general (GCA) and Specific (SCA) combining ability variances for all studied traits are presented in Table 2. Both general combining ability and specific combining ability variances were found to be highly significant for all characters. This would indicate the importance of both additive and nonadditive genetic variances in determining the performance of these nine studied characters. The question remains would be about the relative importance of the type of gene action involved in the inheritance of these traits, therefore, GCA/SCA ratio was used to charity the nature of the gene action involved. The
GCA/SCA variance were found to be greater than unity for days to heading and 1000-grain weight, indicating that, additive and additive $\times$ additive types of gene action were the greater importance in this traits but for the other traits the non-additive type, were great important in plant height, No. of panicle plant ${ }^{-1}$, grain yield plant ${ }^{-1}$, spikelets fertility $\%$, hulling $\%$, milling $\%$ and head rice\%.

It could be concluded that selection procedures based on the accumulation of additive effects would be successful in improving the days to heading and 1000grain weight traits. However, to maximize selection advance, procedures which are known to be effective in shifting gene frequency when both additive and nonadditive genetic variance are involved, would be preferred. Both general and specific combining ability variances were also found for all traits by El-Refaee (2002); Huang et al., (2008); El-Agamy et al., (2008) Saidaiah et al., (2010) and Kelah (2012).

\section{3-1- General combining ability effects:-}

Estimates of general combining ability effects (gi) for individual parental line for all characters are presented in Table (3). Theoretically, an estimate of GCA effects of a line depends upon the group of lines to which it was crossed in the diallel crossing system. If the line is exactly as the average in its general combining ability effect, the expected estimate of (gi) would be zero. Significant departure from zero, where ever the direction would indicate that the line is much better or much worse than the overall average of the parental lines involved.

Table 2. Mean squares estimates of ordinary analysis and combining ability for all studied characters

\begin{tabular}{|c|c|c|c|c|c|c|c|c|c|c|}
\hline S. V & d.f & $\begin{array}{l}\text { Plant } \\
\text { height } \\
(\mathrm{cm})\end{array}$ & $\begin{array}{l}\text { Days to } \\
\text { heading } \\
\text { (days) }\end{array}$ & $\begin{array}{c}\text { No. of } \\
\text { panicles } \\
\text { plant }^{-1}\end{array}$ & $\begin{array}{c}\text { Grain } \\
\text { yield } \\
\text { plant }^{-1} \\
(\mathrm{~g})\end{array}$ & $\begin{array}{c}1000- \\
\text { grain } \\
\text { weight } \\
(\mathrm{g})\end{array}$ & $\begin{array}{c}\text { Spikelets } \\
\text { fertility } \\
\%\end{array}$ & $\begin{array}{c}\text { Hulling } \\
(\%)\end{array}$ & $\begin{array}{c}\text { Milling } \\
(\%)\end{array}$ & $\begin{array}{c}\text { Head } \\
\text { rice }(\%)\end{array}$ \\
\hline Replications & 2 & 0.057 & 0.009 & 0.186 & 0.861 & 0.221 & 0.185 & 0.192 & 0.062 & 0.053 \\
\hline Genotypes & 35 & $229.9^{* *}$ & $199.2^{* * *}$ & $19.20 * *$ & $685.7 * *$ & $2.154 * *$ & $264.0^{* *}$ & $48.11^{* *}$ & $54.09 * *$ & $6.154 * *$ \\
\hline Parents & 7 & $986.7 * *$ & $97.69 * *$ & $23.81 * *$ & $878.6^{* *}$ & $15.16^{* *}$ & $412.2^{* *}$ & $17.21^{* *}$ & $9.140 * *$ & $5.142 * *$ \\
\hline Crosses & 27 & $1818^{* * *}$ & $649.6 * *$ & $203.8^{* *}$ & $7505^{* * *}$ & $58.11 * *$ & $6775 * *$ & $27.64 * *$ & $24.94^{* *}$ & $18.817 * *$ \\
\hline P vs. $F_{1}$ & 1 & $5244 * *$ & $6227^{* *}$ & $444.6^{* *}$ & $15618 * *$ & $2.12 * *$ & $2052^{* * *}$ & $1639 * *$ & $1859 * *$ & $191.4^{* *}$ \\
\hline Error & 70 & 3.944 & 1.152 & 0.695 & 3.348 & 0.356 & 1.441 & 0.354 & 0.244 & 0.471 \\
\hline G.C.A & 7 & $61.96^{* *}$ & $134.0 * *$ & $4.026^{* *}$ & $95.42 * *$ & $1.109 * *$ & $36.11^{* *}$ & $0.299 * *$ & $0.169 * *$ & $1.563 * *$ \\
\hline S.C.A & 28 & $80.34 * *$ & $49.51 * *$ & $6.996^{* *}$ & $261.8^{* *}$ & $0.620 * *$ & $100.9 * *$ & $19.971 * *$ & $22.49 * *$ & $2.173 * *$ \\
\hline Error & 70 & 1.314 & 0.384 & 0.231 & 1.116 & 0.118 & 0.480 & 0.118 & 0.081 & 0.157 \\
\hline GCA/SCA & & 0.771 & 2.707 & 0.575 & 0.364 & 1.788 & 0.357 & 0.014 & .0075 & 0.719 \\
\hline
\end{tabular}

*and**, significant and highly significant, respectively. 
Table 3. General combining ability effect for all studied characters

\begin{tabular}{|c|c|c|c|c|c|c|c|c|c|}
\hline Parents & $\begin{array}{c}\text { Plant } \\
\text { height } \\
(\mathrm{cm}) \\
\end{array}$ & $\begin{array}{c}\text { Days to } \\
\text { heading } \\
\text { (days) }\end{array}$ & $\begin{array}{c}\text { No. of } \\
\text { panicles } \\
\text { plant }^{-1} \\
\end{array}$ & $\begin{array}{c}\text { Grain yield } \\
\text { plant }^{-1} \\
\text { (g) }\end{array}$ & $\begin{array}{c}\text { 1000-grain } \\
\text { weight } \\
\text { (g) } \\
\end{array}$ & $\begin{array}{c}\text { Spikelets } \\
\text { fertility \% }\end{array}$ & $\begin{array}{l}\text { Hullin } \\
\text { g (\%) }\end{array}$ & $\begin{array}{c}\text { Milling } \\
(\%)\end{array}$ & $\begin{array}{c}\text { Head } \\
\text { rice }(\%)\end{array}$ \\
\hline Giza 177 & $-2.86^{*}$ & -0.30 & -0.14 & 0.08 & $0.550 *$ & $1.19 * *$ & -0.196 & $1.190^{* * *}$ & $1.108 * *$ \\
\hline Sakha 101 & $-2.74 *$ & $7.45 * *$ & $1.08 * *$ & $5.71 * *$ & -0.13 & $-4.05 * *$ & $-1.135 * *$ & -0.148 & -0.057 \\
\hline Sakha 104 & $3.83 *$ & $3.65 * *$ & $-0.92 * *$ & $2.49 * *$ & $-0.57 *$ & 0.54 & $1.213^{* * *}$ & 0.086 & $1.178^{* * *}$ \\
\hline Sakha 105 & 0.78 & $-1.64 * *$ & 0.24 & -0.57 & 0.20 & $-1.27 * *$ & -0.056 & $1.038 * *$ & $1.265^{* *}$ \\
\hline Sakha 106 & $2.36^{*}$ & $-2.64 * *$ & 0.18 & 0.91 & 0.34 & 0.28 & $-1.163 * *$ & $1.129 * *$ & -0.467 \\
\hline GZ 7576-10-3-2-1 & 0.71 & $-2.54 * *$ & 0.16 & $-3.18 * *$ & -0.19 & $2.16^{* *}$ & 0.077 & 0.154 & $1.112 * *$ \\
\hline BL 1 & 0.36 & $-1.40 * *$ & 0.18 & $-1.79 * *$ & 0.048 & 0.44 & 0.267 & $1.010^{* *}$ & 0.116 \\
\hline Shien 2 & $-2.45^{*}$ & $-2.57 * *$ & $-0.77 *$ & $-3.66 * *$ & -0.24 & 0.69 & -1.008 & -0.103 & $0.856^{*}$ \\
\hline L.S.D. $5 \%$ & 1.008 & 0.426 & 0.594 & 1.027 & 0.546 & 0.720 & 0.740 & 0.652 & 0.802 \\
\hline $1 \%$ & 1.491 & 0.630 & 0.879 & 1.519 & 0.808 & 1.065 & 1.096 & 0.965 & 1.187 \\
\hline
\end{tabular}

*and**, significant and highly significant, respectively.

General combining ability effects computed herein were found to be differing significantly from zero in most cases. High positive values of GCA effects would be of interest in most traits under investigation. However, high negative values for days to heading and plant height would be useful from the breeder's point of view. The five rice varieties Sakha105, Sakha106, GZ7576-10-3-2-1, BL1 and Shien2 showed highly significant negative GCA effects for days to heading, revealing that these varieties could be considered as good combiners for developing early genotypes. As for plant height, Giza177, Sakha101 and Shien2 exhibited significant negative GCA effects. Proving to be good combiners for dwarfism. This conclusion was also drawn by Singh and Kumar (2005); Saidaiah et al., (2010) and Selvaraj et al., (2011).

As for No. of panicles plant ${ }^{-1}$, Sakha 101 exhibited highly significant positive GCA effects, proving to be good combiner for this trait. Giza177, showed significant positive GCA effect for 1000-grain weight, proving to be good combiner in this concern. The two rice varieties Sakha101 and Sakha104 showed highly significant positive GCA effects for grain yield plant ${ }^{-1}$, proving to be excellent combiners for this trait. It could be concluded that the two rice varieties Sakha101 and Sakha104 which proved to be excellent combiners for grain yield plant ${ }^{-1}$ would be of practical interest in a breeding program towards developing high yielding genotypes because of their superiority in at least two of the grain yield contributory. This conclusion was also drawn by Abd Allah (2008) and Kelah (2012).

Sakha104 showed highly significant desirable GCA effects for hulling \%, proving to be good combiners in this concern. As for milling \%, two rice varieties Giza177, Sakha105 and Sakha106 showed highly significant desirable GCA effects proving to be good general combiner for this character. Concerning head rice \% two rice varieties, Sakha101 and Sakha106 showed negative significant GCA effects indicated that two varieties good combiners in this concern. It is of interest to mention that Giza177 and Sakha106 proved to be good combiner for most grain character studied. The results reported by Hammoud (2004) and Hassan el al., (2011).

\section{3-2- Specific combining ability effects $(\mathrm{Sij})$ :-}

Estimates of the specific combining ability effects (Sij) for the parental combinations for all studied characters are given in Table (4). The significant desirable interallelic interaction would only be discussed here. Fourteen of the twenty eight hybrid combinations studied showed highly significant negative SCA effects for days to heading. Two of there thirteen crosses were found to show useful heterosis Sakha101xSakha104 and Sakha106xGZ7576-10-2-3-1 (Table 4). It is of interest to note that some of the rice varieties which were involved in these superior thirteen crosses were found to be among the best combinations and others were among the poorest combiners for days to heading. For plant height, one hydride combination Sakha105 x Sakha106 was detected to exhibited negative highly significant desirable SCA effects. Eighteen out of the twenty eight hybrid combinations in vestigated showed significant and highly significant SCA effects for No. of panicles plant $^{-1}$. These excellent eighteen crosses were previously found to express useful heterosis.

Twenty out of the twenty eight hybrid combinations studied exhibited highly significant desirable SCA effects for grain yield plant ${ }^{-1}$. These superior twenty crosses were previously found to express useful heterosis. As for 1000-grain weight, two crosses showed highly significant SCA effects Sakha105 x Shien2 and Gz7576-10-3-2-1 x BL1 these crosses which showed highly significant heterosis. It is for interest to mention that the four rice varieties Sakha105, Shein2, Gz7576- 
10-3-2-1 and BL1 were found to be among the poor combiner for 1000-grain weight. However, ten of the twenty eight hydride combinations exhibited highly significant SCA effects spikelets fertility\%. Twenty six crosses showed significant and highly significant desirable SCA effects for hulling \%, three crosses were previously found to express useful heterosis.

Also some of the parental varieties which involved in these crosses were found to be among the best combiner for hulling $\%$ and the other were among the poorest combiners for this trait except Sakha101 x Shein2 and BL1 x Shein2. Nine out of the twenty eight hybrid combination investigated showed highly significant SCA effects for milling \%. Six crosses from these nine crosses which showed highly significant heterosis. It is of interest to mention that the three rice verities Sakha101, Sakha104 and Sakha105 were found to be among the poor combiners for milling\%. As for head rice $\%$, six hybrid combinations showed significant and highly significant SCA effects, three of them were previously showed highly significant desirable heterosis.

The results obtained here concerning general and specific combining ability effects could indicate that the excellent crosses which showed desirable SCA effects were obtained from crossing good by good, good by low and low by low combiners. Consequently, it could be

\section{Table 4. Stimates of specific combining ability effects (Sij) for all studied characters}

\begin{tabular}{|c|c|c|c|c|c|c|c|c|c|}
\hline Crosses & $\begin{array}{c}\text { Plant } \\
\text { height } \\
(\mathrm{cm})\end{array}$ & $\begin{array}{c}\text { Dayso } \\
\text { heading } \\
\text { (days) }\end{array}$ & $\begin{array}{c}\text { No.of } \\
\text { panicles } \\
\text { plant }^{-1}\end{array}$ & $\begin{array}{c}\text { Grain yield } \\
\text { plant }^{-1}\end{array}$ & $\begin{array}{c}\text { 1000-grain } \\
\text { weight }\end{array}$ & $\begin{array}{c}\text { Spikelet } \\
\text { fertility \% }\end{array}$ & $\begin{array}{c}\text { Hulling } \\
(\%)\end{array}$ & $\begin{array}{c}\text { Milling } \\
(\%)\end{array}$ & $\begin{array}{c}\text { Head rice } \\
(\%)\end{array}$ \\
\hline Giza 177×SaKha101 & -0.41 & $3.47 * *$ & $0.90^{*}$ & $5.734 * *$ & 0.403 & $5.569 * *$ & $2.196^{* * *}$ & $-2.05 * *$ & 0.695 \\
\hline Giza $177 \times$ Sakha 104 & -0.66 & $-7.73^{* *}$ & $1.81^{* *}$ & $8.119 * *$ & -0.16 & $8.798^{* *}$ & $1.854 * *$ & $-2.08 * *$ & $-1.330^{*}$ \\
\hline Giza $177 \times$ Sakha 105 & $5.19 * *$ & $11.57 * *$ & $1.04 *$ & -0.96 & 0.567 & $-2.58 * *$ & $2.073 * *$ & $-2.60 * *$ & $-2.31 * *$ \\
\hline Giza 177× Sakha 106 & $2.044 *$ & $0.57 * *$ & $2.103^{* *}$ & $18.25 * *$ & -0.08 & $-2.14 * *$ & $1.500^{*}$ & $-2.60 * *$ & $1.356^{*}$ \\
\hline Giza $177 \times$ GZ 7576-10-3-2-1 & -0.5 & $-0.2 * *$ & $1.92 * *$ & $7.784 * *$ & 0.43 & $-7.85^{* *}$ & $1.503^{*}$ & $-2.58 * *$ & $-2.60 * *$ \\
\hline Giza $177 \times$ BL 1 & 1.517 & $-0.66^{* *}$ & $1.73 * *$ & $2.723 * *$ & -0.01 & $-9.8^{* *}$ & $2.113^{* *}$ & $-3.26 * *$ & 0.419 \\
\hline Giza $177 \times$ Shien 2 & $6.87 * *$ & $2.50 * *$ & 0.4 & $-2.07 * *$ & 0.654 & $-11.4 * *$ & $1.813^{* *}$ & $-2.31 * *$ & 0.57 \\
\hline Sakha $101 \times$ Sakha 104 & $5.983 * *$ & $-12.49 * *$ & 0.85 & $9.012 * *$ & -0.01 & $5.688^{* *}$ & $1.543^{* *}$ & $-1.99 * *$ & $-1.32 *$ \\
\hline Sakha $101 \times$ Sakha 105 & $10.5 * *$ & $-14.2^{* *}$ & $1.35^{* *}$ & $4.439 * *$ & -0.35 & 0.914 & $2.303 * *$ & $-2.40 * *$ & $2.439 *$ \\
\hline Sakha 101× Sakha 106 & 0.354 & $10.8^{* *}$ & 0.74 & $-7.23 * *$ & -0.06 & $-10.4 * *$ & $2.453^{* * *}$ & $-1.73 * *$ & $-1.85 * *$ \\
\hline Sakha $101 \times$ GZ 7576-10-3-2-1 & 0.907 & $7.70 * *$ & $-1.04 *$ & $20.05^{* *}$ & $-1.16^{* *}$ & $-10.5^{* *}$ & $2.41 * *$ & $-2.08 * *$ & $-1.77 * *$ \\
\hline Sakha $101 \times$ BL 1 & $1.69^{*}$ & $4.57 * *$ & $3.30 * *$ & $5.499 * *$ & 0.099 & $-9.5^{* *}$ & $2.109^{* *}$ & $-2.93 * *$ & -0.026 \\
\hline Sakha $101 \times$ Shien 2 & $6.84 * *$ & $10.74 * *$ & $1.93 * *$ & $10.59 * *$ & $-1.44 * *$ & $-13.2 * *$ & 1.025 & $-3.36 * *$ & 0.127 \\
\hline Sakha 104× Sakha 105 & $9.487 * *$ & $14.6^{* *}$ & $1.93 * *$ & $6.718^{* *}$ & -0.68 & $-20.8 * *$ & $2.440^{* *}$ & $-1.99 * *$ & -0.290 \\
\hline Sakha $104 \times$ Sakha 106 & 0.107 & $-2.4 * *$ & $1.48^{* * *}$ & $16.38 * *$ & -0.23 & $2.711^{* *}$ & $2.634 * *$ & $-2.49 * *$ & -0.085 \\
\hline Sakha 104×GZ7576-10-3-2-1 & $6.66 * *$ & $10.5^{* *}$ & -0.49 & $-6.57 * *$ & 1.28 & 0.196 & $2.650 * *$ & $-2.26 * *$ & $-1.79 * *$ \\
\hline Sakha $104 \times$ BL 1 & 0.914 & $1.37 * *$ & $-1.11^{*}$ & $8.135^{* *}$ & -0.43 & $-17.8^{* * *}$ & $1.130 *$ & $-2.49 * *$ & 1.145 \\
\hline Sakha $104 \times$ Shien 2 & $4.367 * *$ & $1.53 * *$ & -0.48 & $9.445^{* * *}$ & -0.26 & $-2.82 * *$ & $2.186^{* *}$ & $-2.60 * *$ & $1.248^{*}$ \\
\hline Sakha $105 \times$ Sakha 106 & $-2.64 * *$ & $-3.1^{* *}$ & 0.45 & $-7.21 * *$ & 0.1 & $-4.44 * *$ & $1.940 * *$ & $-1.72 * *$ & $2.062^{*}$ \\
\hline Sakha $105 \times$ GZ 7576-10-3-2-1 & -0.16 & $-2.2 * *$ & $0.84 *$ & $7.136 * *$ & 0.274 & 0.335 & $1.556^{* *}$ & $-2.05^{* * *}$ & $1.681 *$ \\
\hline Sakha $105 \times$ BL 1 & $5.064 * *$ & -0.33 & $1.88^{* *}$ & $21.38 * *$ & 0.067 & $3.355^{* * *}$ & $2.886^{* *}$ & -0.894 & -0.031 \\
\hline Sakha $105 \times$ Shien 2 & $7.217 * *$ & $-2.16^{* * *}$ & -0.82 & $3.445^{* *}$ & $0.864 *$ & $5.919 * *$ & $2.406^{* *}$ & -0.972 & -1.058 \\
\hline Sakha 106× GZ 7576-10-3-2-1 & $1.564^{*}$ & $-3.53^{* *}$ & $2.76^{* *}$ & $-4.19^{* *}$ & 0.559 & $-7.59 * *$ & $2.573^{* *}$ & $-1.95^{* *}$ & -0.411 \\
\hline Sakha $106 \times$ BL 1 & $10.95^{* *}$ & $4.004^{* *}$ & $1.77 * *$ & $19.49 * *$ & -0.18 & $-1.24 *$ & $2.163^{* *}$ & $-1.98 * *$ & 0.698 \\
\hline Sakha $106 \times$ Shien 2 & $6.87 * *$ & $-2.16^{* *}$ & $1.13^{*}$ & $7.421 * *$ & 0.383 & $10.05^{* *}$ & $2.760 * *$ & $-1.38^{* *}$ & 0.084 \\
\hline GZ 7576-10-3-2-1× BL 1 & $4.704 * *$ & $-3.43^{* *}$ & $1.29 * *$ & $-3.31 * *$ & $1.793^{* *}$ & $7.166^{* *}$ & $2.643^{* *}$ & $-2.03 * *$ & $1.496^{*}$ \\
\hline GZ 7576-10-3-2-1× Shien 2 & $6.724 * *$ & $-2.26^{* *}$ & $3.06^{* *}$ & $21.61 * *$ & 0.09 & $8.723^{* *}$ & $2.662^{* * *}$ & $-2.52 * *$ & 0.816 \\
\hline BL $1 \times$ Shien 2 & $2.11 * *$ & $-4.4 * *$ & -0.43 & $-1.83 *$ & -0.45 & $7.316^{* *}$ & 0.916 & $-2.54 * *$ & -0.822 \\
\hline \multirow[t]{2}{*}{ L.S.D. $\quad 5 \%$} & 1.528 & 0.647 & 0.901 & 1.557 & 0.828 & 1.092 & 1.123 & 0.989 & 1.217 \\
\hline & 2.062 & 0.872 & 1.216 & 2.101 & 1.117 & 1.473 & 1.515 & 1.334 & 1.642 \\
\hline
\end{tabular}

*and**, significant and highly significant, respectively. 
concluded that GCA effects of the parental varieties were generally unrelated to the specific combining ability effects of their respective crosses. This conclusion was also drawn by Aidy and Maximos (2006); Sedeek (2006) and Chakraborty et al., (2010).

\section{Cluster analysis:}

Clustering of varieties based on similarity of morphological characters. Table (5) showed the similarity matrix of nine morphological agronomic characters for eight parents. Clustering varieties based on similarity of quantitative characters produced two groups (Figure1). The first included; Sakha101 and Sakha104, this in group one, two varieties were similar in heading (average is 107.5 days), and highest grain yield plant ${ }^{-1}$. These tow varieties were similar at hulling\% and head rice\%. While, the second group included; Giza177, Gz 7576-10-3-2-1, BL1, Sakha105, Sakha106 and Shien2. This group included all short days to heading varieties (average is 91.6 days) and were similar at No. of panicles plant ${ }^{-1}$. This group was divided into two sub groups, the firest sub group included Shien2 alone. This variety has the lowest values for plant height, spikelets fertility $\%$ and grain yield plant ${ }^{-1}$ characters. The second sub group included; Giza177, GZ7576-10-3-2-1, BL1, Sakha105 and Sakha106. this group divided into two sub group, the sub sub group included Sakha105 and Sakha106 in which both varieties were similar at 1000 -grain weight, milling $\%$ and head rice $\%$. Second sub sub groups included Giza177, GZ7576-10-3-2-1 and BL1. This group divided into two sub groups, the firest sub sub sub groups included GZ7576-10-3-2-1 and BL1 in which both varieties gave the same values for No. of panicle plant $^{-1}$, and hulling $\%$. Finally, the results gave Giza177 variety in one bereuch because this variety recorded the lowest values for No. of panicles plant ${ }^{-1}$. These resulted were also obtained by El-Moghazy (2007); Anees (2009) and Sedeek et al., (2009).

Dendogram of eight rice varieties based on 9 quantitative charaters

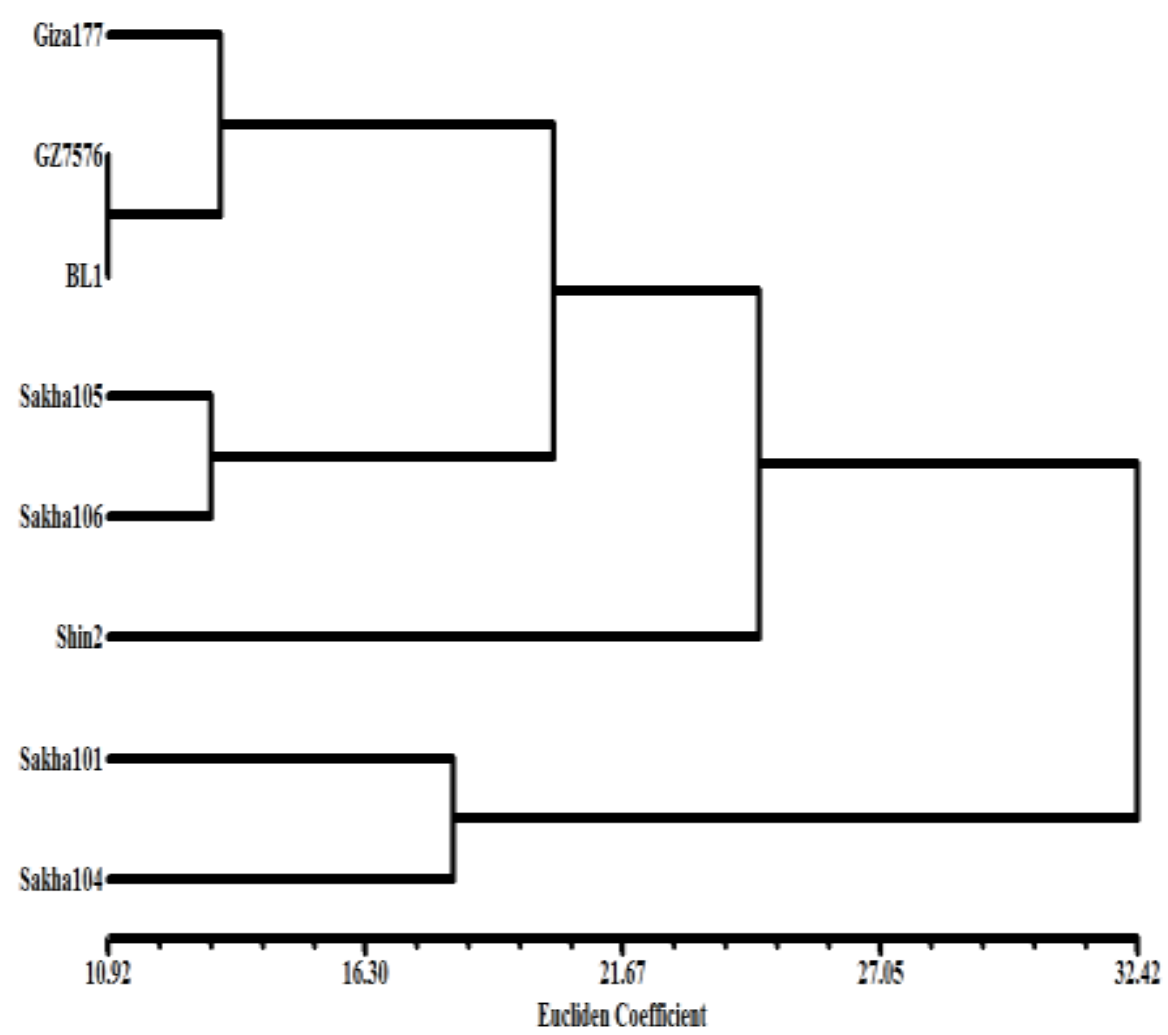

Figure 1. Cluster diagram for eight varieties classified by nine morphological quantitative characters 
Table 5. Similarity matrix for eight varieties based on nine morphological characters

\begin{tabular}{|c|c|c|c|c|c|c|c|c|}
\hline & Giza177 & Sakha101 & Sakha104 & Sakha105 & Sakha106 & $\begin{array}{c}\text { GZ7576- } \\
\text { 10-3-2-1 }\end{array}$ & BL1 & Shien2 \\
\hline Giza177 & 0.00 & & & & & & & \\
\hline Sakha101 & 3.691 & 0.00 & & & & & & \\
\hline Sakha104 & 3.273 & 1.813 & 0.00 & & & & & \\
\hline Sakha105 & 1.782 & 2.489 & 2.260 & 0.00 & & & & \\
\hline Sakha106 & 2.405 & 2.747 & 1.759 & 1.307 & 0.00 & & & \\
\hline $\begin{array}{c}\text { GZ7576- } \\
10-3-2-1\end{array}$ & 1.326 & 3.651 & 2.900 & 1.615 & 1.831 & 0.00 & & \\
\hline BL1 & 1.328 & 3.980 & 3.371 & 1.994 & 2.510 & 1.092 & 0.00 & \\
\hline Shien2 & 2.304 & 4.436 & 4.340 & 2.486 & 3.393 & 2.238 & 1.835 & 0.00 \\
\hline
\end{tabular}

\section{REFERENCES}

Abd Allah, R. M. A. (2008). Genetical and morphological studies on environmental and cytoplasmic male sterility in rice. M.Sc.; Thesis, Genetic Dept. Fac. Of Agric., Mansoura Univ., Egypt.

Aidy, I. R. and M.A. Maximos (2006). Rice varietal improvement in Egypt during the last two decades: achievements and future strategies. Egypt., J. Agric. Res.

Anees, G.B. (2009). Breeding for earliness and some agronomic characters in rice (Oryza sativa L.). M.Sc Thesis, Fac. Agric. Kafr El-Sheikh Tanta Univ., Egypt.

Butany, W.T. (1961). Mass emasculation in rice. Intern. Rice Com. Newsletter, 9:9-13.

Chakraborty, R.; S. Chakraborty; B. K. Dutta and S. B. Paul (2010). Combining ability analysis for yield and yield components in bold grained rice (Oryza sativa L.) of Assam. Acta. Agron. (Palmira). 58(1): 9-13.

Duwayri, M.; D. V. Tran and V. N. Nguyen (1999). Reflection on yield gaps in rice production. Intr. Rice Commission Newsletter. FAO, Rome (48): 13-25.

El-Agamy, A.L.; M. A.A. El-Sayed; A.A. El-Hissiwy and M.A. Darwish (2008). Effect of rice husk rates and irrigation intervals on yield and some grain quality of rice. J. Agric. Sci. Mansoura Univ. 33(7): 4791-4801.

El-Malky, M.M and S.A.A Hammoud (2012). Utilization of diallel analysis crosses in developing elite promising lines of rice. Fourth Field Crops Conference, Egypt. (In Pres.)

El-Moghazy, A.M. (2007). Genetical and molecular breeding for drought tolerance in rice. Ph.D Thesis, Fac. Agric., Kafr El-Sheikh Univ., Egypt.

El-Refaee, Y. Z. E. (2002). Genetical and biochemical studies on heterosis and combining ability in rice. M. Sc. Thesis, Fac. Agric., Tanta Univ., Kafr El-Sheikh, Egypt.

Griffing, J. B. (1956). Concept of general and specific combining abilityin relation to diallel crossing system. Aust. J. Biol. Sci., 9:43.

Hammoud, S.A.A.M. (2004). Inheritance of some quantitative characters in rice (Oryza sativa L.). Ph. D. Thesis, Fac. Agric. Minofiya Univ., Shibin El-Kom., Egypt.
Hassan, H.M.; A.B. El-Abd and N.M. El-Baghdady (2011). Combining ability for some root, physiological and grain quality traits in rice (Oryza sativa L.) under water deficit conditions. J. Agric. Rec. Kafer El-Sheikh Univ. 37(2): 239-256.

Huang, D.; L. Xi; Z. Wang; L. Liu and J. Yang (2008). Effects of Irrigation patterns during grain filling on grain quality and concentration and distribution of cadmium in different organs of Rice. Acta Agron., Sci. 34(3): 456-464.

IRRI (1996). International Rice Research Descriptors for Rice. Los Banos, Laguna, Philippines. 52p.

Jodon, N.E. (1938). Experiments on artificial hybridization of rice. J. Amer. Soc. Agron. 30:249-305.

Kelah, M.I.M. (2012) Genetic studies on earliness; yield and its components for some rice genotypes. M.Sc Thesis, Fac. Agric. Kafr El-Sheikh Univ., Egypt.

Rahimi, M.; B. Rabiei; H. Samizadeh and A. Kafi Ghasemi (2010). Combining Ability and heterosis in rice (Oryza sativa L.) cultivars. J. Agric. Sci. Tech. 12: 223-231.

Rohlf, F.J. (2000). NTSYS-PC manual Exeter Software, Setauket, New York.

RRTC (2006). National Rice Research Program: Final results of 2005 growing season. Sakha, Egypt.

Saidaiah, P.; S. Sauder kumar and M.S. Ramesha (2010). Combining ability studies for development of new hybrids in rice over environments. J. of Agric. Sci. 2(2): 225-233.

Sedeek, S. E. M. (2006). Breeding studies on rice. Ph.D. Thesis, Faculty of Agri., Kafr El-Sheikh, Tanta Univ. Egypt.

Sedeek, S.E.M.; S.A.A.M. Hammoud.; M.H. Ammar and T.F. Metwally (2009). Genetic variability, heritability, genetic advance and cluster analysis for some physiological traits and grain yield and its components in rice (Oryza sativa L.). J. Agric. Res. Kafer El-Sheikh Univ. 35(3): 858-878.

Selvaraj, C.; P. Nagarajan.; K. Thiyagarajan.; M. Bharathi and R. Rabindran (2011). Studies heterosis and combining ability of well known blast resistant rice genotypes with high yielding varieties of rice (Oryza sativa L.). Inter. J. of Breed. and Genet. 5(2): 111-129.

Singh, N. K. and A. Kumar (2005). Combining ability analysis to identify suitable parents for heterotic rice hybrid breeding. Inter. Rice Res. Newsletter 29: 21-22. 


\section{الملخص العربي}

\section{تقدير القدره العامه علي الأئتلاف وتحليل الشجره الوراثية لبعض أصناف الأرز}

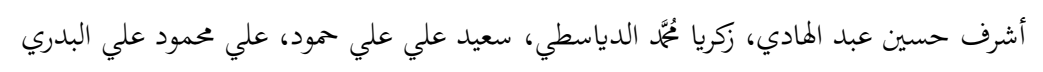

المئوية للتبيض وكذلك النسبة المئوية للتـدريج. وكـان هنـاك خمسـة

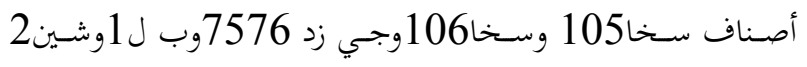

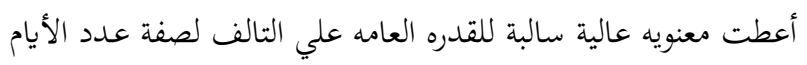
الازمه حتي التزهير, وكان الصنف جيزه

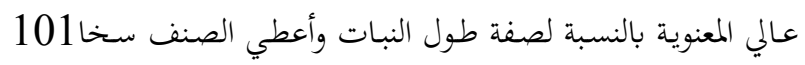

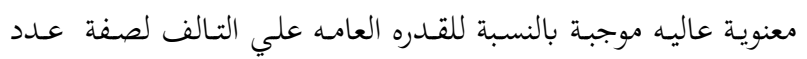

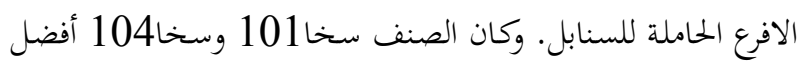

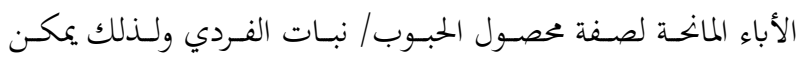

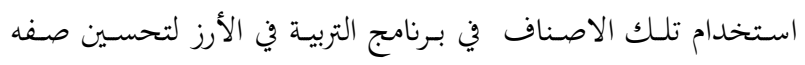

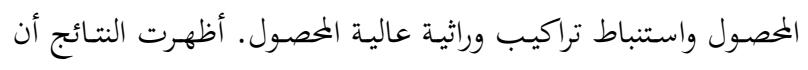

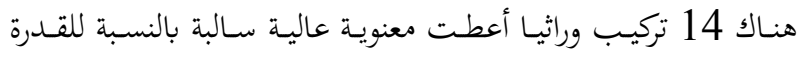

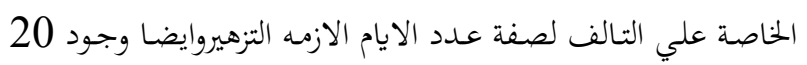

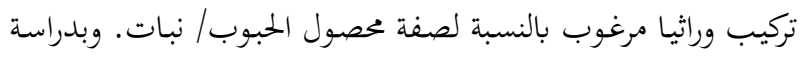

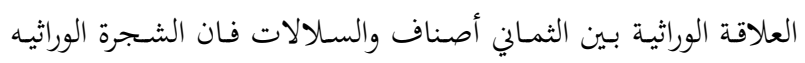

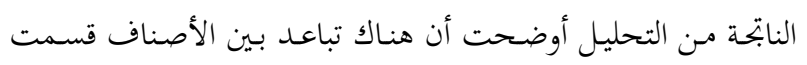

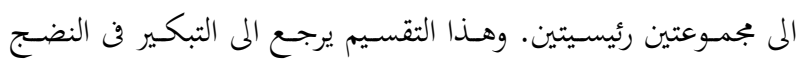

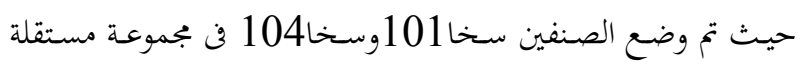
نظرا لطول فترة نضجه.
أجريت هذه الدراسة بالمزرعة البحثية بمركز البحوث والتدريب في

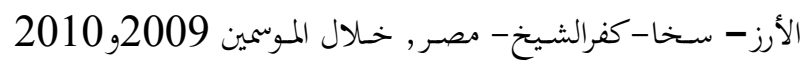

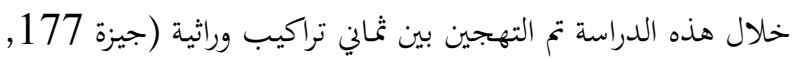

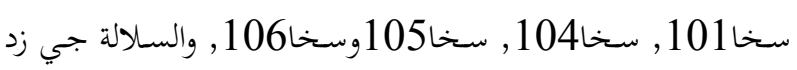

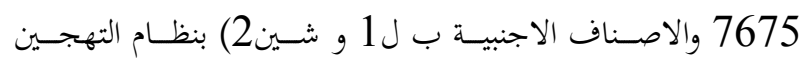

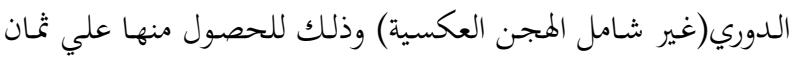
وعشرين هجينا, وتم دراسة الصفات التالية(طول النبات- عدد الايام

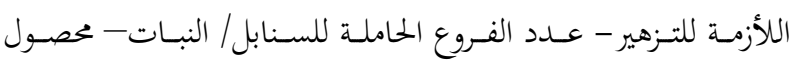
الحبوب نبات- وزن الألف حبة- النسبة المئوية لخصوبة السنيبلات-

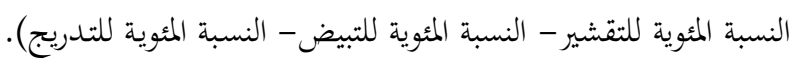
وكان التباين الوراثي الراجع الي التركيب الوراثية والاباء والهجن النابتحة

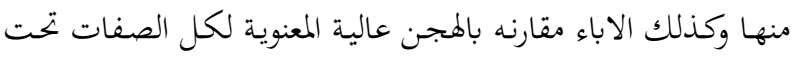
الدراسة وكانت تقديرات القدره العامة والخاصة للئتلاف عالية المعنوية لكل الصفات محل الدراسة وكانت قيمة القدره العامة على الخاصة

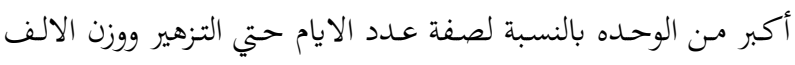

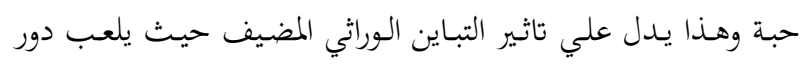

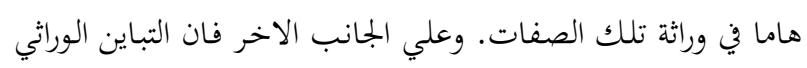

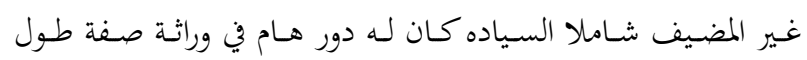

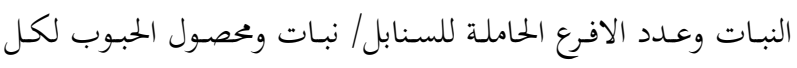

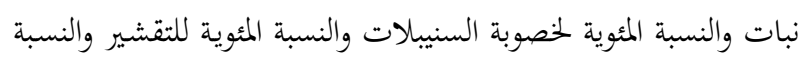

